\title{
DEIKSIS PADA PERTUTURAN MASYARAKAT DESA KALIREJO
}

\author{
Dimas Bagus Laksono ${ }^{1)}$, A. Rahman ${ }^{2)}$, Rohmah Tussolekha ${ }^{3)}$. \\ Pendidikan Bahasa dan Sastra Indonesia, Universitas Muhammadiyah Pringsewu Lampung \\ Pos-el: laksonodimasbagus@gmail.com
}

\begin{abstract}
Abstrak
Tujuan penelitian ini untuk mendeskripsikan pemakaian bentuk-bentuk deiksis pada pertuturan masyarakat Desa Kalirejo, Dusun III B, RT 012, RW 003, Kecamatan Kalirejo, Kabupaten Lampung Tengah. Penelitian ini menggunakan metode deskriptif kualitatif. Penelitian ini menggunakan analisis data model Miles and Huberman. Berdasarkan hasil analisis data ditemukan tuturan yang mengandung deiksis, yaitu deiksis persona, deiksis tempat, dan deiksis waktu. Deiksis yang paling banyak ditemukan adalah deiksis persona. Deiksis dapat dimanfaatkan sebagai sumber belajar pada pembelajaran Bahasa Indonesia di SMA kelas XI dapat memberikan pemahaman mengenai pemilihan kata (diksi) dan keefektifan kalimat pada pembelajaran menulis teks cerpen.

Kata kunci: Deiksis, Pertuturan, Pragmatik.
\end{abstract}

\begin{abstract}
The purpose of this study was to describe the use of deixis forms in the speech of the people of Kalirejo Village, Hamlet III B, RT 012, RW 003, Kalirejo District, Central Lampung Regency. This research uses a qualitative descriptive method. This study uses data analysis of the Miles and Huberman model. Based on the results of data analysis found speech that contains deixis, namely persona deixis, place deixis, and time deixis. The most commonly found deixis is persona deixis. Deixis can be used as a learning resource in learning Indonesian in high school class XI can provide an understanding of word choice (diction) and the effectiveness of sentences in learning to write short text. Keywords: Deixis, Speech, Pragmatics.
\end{abstract}




\section{PENDAHULUAN}

Dalam kehidupan sehari-hari manusia selalu berinteraksi dengan manusia lain. Dalam berinteraksi manusia menggunakan bahasa, baik secara lisan maupun tulisan sebagai sarana berkomunikasi. Hal ini berarti bahasa tidak pernah lepas dari kehidupan manusia. Oleh karena itu, fungsi utama bahasa adalah sebagai alat komunikasi atau alat interaksi antarmanusia. Tanpa adanya sebuah bahasa maka seseorang tidak akan bisa berkomunikasi dan menukarkan pikiran dengan orang lain.

Bahasa dikaji dalam linguistik. Menurut Martinet (dalam Chaer, 2012:6) "Linguistik merupakan telaah ilmiah mengenai bahasa manusia". Sebagai ilmu kajian bahasa linguistik memiliki beberapa cabang ilmu. Diantaranya cabang-cabang ilmu itu ialah Fonologi, Morfologi, Sintaksis, Semantik, dan Pragmatik. Menurut Tarigan (dalam Rahardi dkk, 2016:18) "Menegaskan bahwa telaah umum mengenai bagaimana konteks memengaruhi cara menafsirkan kalimat disebut pragmatik". Dengan demikian, melalui pragmatik dapat menafsirkan kalimat dengan memerhatikan konteks. Salah satu kajian pragmatik adalah deiksis. Deiksis adalah istilah teknis (dari bahasa Yunani) untuk salah satu hal mendasar yang dilakukan dengan tuturan. Deiksis berarti penunjukan melalui bahasa. Bentuk linguistik yang dipakai untuk menyelesaikan penunjukan disebut ungkapan deiksis. Sebuah kata dikatakan bersifat deiksis apabila referennya berpindah-pindah atau berganti-ganti, bergantung pada saat dan tempat dituturkan kata itu (Yule, 2014:13).

Berdasarkan observasi, ditemukan permasalahan bahwa fenomena deiksis secara tidak langsung dapat terjadi pada suatu tuturan masyarakat. Deiksis yang digunakan pada suatu tuturan sering berubah-ubah bergantung pada konteks dalam tuturan tersebut. Untuk memahami dan menentukan sebuah ujaran yang bersifat deiksis pada suatu pertuturan masyarakat diperlukan pemahaman yang menyeluruh mengenai pengetahuan deiksis, karena deiksis mengacu pada referen yang tidak menetap pada satu maujud. Senada dengan pendapat Chaer (2010:291) berkenaan dengan acuan ini ada sejumlah kata, yang disebut kata-kata diektik, yang acuannya tidak menetap pada satu maujud yang lain.

Deiksis pada pertuturan masyarakat menjadi hal yang penting untuk diteliti karena suatu pertuturan yang terjadi di masyarakat memungkinkan adanya pemakaian bentuk-bentuk deiksis. Dengan 
melakukan penelitian ini peneliti ingin mengetahui dan mempelajari mengenai pemakaian bentuk-bentuk deiksis yang ada pada masyarakat Desa Kalirejo. Penelitian ini diharapkan dapat membantu semua orang dalam memahami apa itu deiksis dan bagaimana bentuk-bentuk deiksis pada pertuturan dalam kehidupan sehari-hari. Sehingga dengan memahami deiksis dapat terjadi penggunaan bahasa yang efektif, baik, dan benar. Karena deiksis dapat dimanfaatkan pada pemilihan kata dan penggunaan kalimat yang efektif. Oleh karena itu, peneliti tertarik melakukan penelitian yang berjudul "Deiksis Pada Pertuturan Masyarakat Desa Kalirejo" sebagai bahan kajian untuk mendeskripsikan deiksis persona, deiksis tempat, dan deiksis waktu pada pertuturan masyarakat Desa Kalirejo, Dusun III B, RT 012, RW 003, Kecamatan Kalirejo, Kabupaten Lampung Tengah. Penelitian ini memiliki relevansi dengan bahan ajar Bahasa Indonesia di SMA kelas XI berbasis kurikulum 2013. Relevansi penelitian ini dengan pembelajaran Bahasa Indonesia di SMA kelas XI dapat dimanfaatkan pada pembelajaran menulis teks cerpen.

\section{METODE PENELITIAN}

Metode yang digunakan dalam penelitian ini adalah deskriptif kualitatif. Metode ini digunakan peneliti untuk mendeskripsikan pemakaian bentukbentuk deiksis yang terdapat dalam tuturan masyarakat Desa Kalirejo, Dusun III B, RT 012, RW 003, Kecamatan Kalirejo, Kabupaten Lampung Tengah. Data penelitian ini adalah bentuk atau wujud deiksis, data-data diperoleh dari hasil teknik sadap, teknik simak libat cakap, teknik simak bebas libat cakap, teknik rekam, dan teknik catat serta wawancara kemudian dianalisis sesuai dengan bentuk deiksis yang muncul pada pertuturan masyarakat Desa Kalirejo.

Peneliti melakukan penelitian di Desa Kalirejo, Dusun III B, RT 012, RW 003, Kecamatan Kalirejo, Kabupaten Lampung Tengah pada tahun 2019. remaja umur 15-21 tahun sebagai informan penelitian. Menurut Arikunto (2010:173) populasi adalah keseluruhan subjek penelitian. Populasi dalam penelitian ini adalah remaja Desa Kalirejo, Dusun III B, RT 012, RW 003, Kecamatan Kalirejo, Kabupaten Lampung Tengah sejumlah 103 remaja yang ditemukan pada $53 \mathrm{KK}$ dari jumlah total KK yaitu 131 KK (Kartu Keluarga).

Menurut Arikunto (2010:174) sampel adalah sebagian atau wakil 
populasi yang diteliti. Pengambilan sampel dalam penelitian ini menggunakan pendapat Arikunto “Apabila jumlah subjeknya kurang dari 100, maka lebih baik diambil semuanya, dan apabila lebih dari 100, maka dapat diambil 10\% sampai $15 \%$ atau 20\% sampai 25\%". Populasi remaja Desa Kalirejo, Dusun III B, RT 012, RW 003, Kecamatan Kalirejo, Kabupaten Lampung Tengah adalah sejumlah 103 remaja. Berdasarkan populasi tersebut diambil $10 \%$ dari populasi maka jumlah sampelnya adalah $10 \% \times 103=10,3$ dibulatkan menjadi 10 sehingga diperoleh 10 sampel data pertuturan remaja.

Adapun teknik pengambilan sampel dengan teknik purposive sampling. Purposive sampling adalah teknik penentuan sampel dengan pertimbangan tertentu atau tujuan tertentu (Sugiyono, 2017:124). Teknik ini dilakukan karena beberapa pertimbangan yaitu alasan keterbatasan waktu, tenaga, dan dana sehingga tidak dapat mengambil sampel yang besar dan jauh.

Pemeriksaan keabsahan data dalam penelitian ini menggunakan triangulasi data. Wiersma (dalam Sugiyono, 2017:372) triangulasi dalam pengujian kredibilitas ini diartikan sebagai pengecekan data dari berbagai sumber dengan berbagai cara, dan berbagai waktu. dikembangkan pola hubungan tertentu atau menjadi hipotesis. Teknik analisis data pada penelitian ini dilakukan dengan analisis data model Miles and Huberman. Aktivitas langkah-langkah dalam analisis data, yaitu data reduction (reduksi data), data display (penyajian data), dan conclusion/verification (penarikan kesimpulan) (Miles and Huberman dalam Sugiyono 2017:337).

\section{HASIL DAN PEMBAHASAN}

Bentuk-bentuk deiksis yang ditemukan pada pertuturan masyarakat Desa Kalirejo dikelompokkan menjadi tiga bentuk deiksis, yaitu bentuk deiksis persona, tempat, dan waktu. Berdasarkan hasil analisis dan pengolahan data jumlah keseluruhan tuturan masyarakat Desa Kalirejo yang berfokus pada informan remaja mengandung bentuk deiksis yaitu dimana masing-masing terbagi menjadi deiksis persona, deiksis tempat, dan deiksis waktu.

Penelitian ini memiliki relevansi dengan bahan ajar Bahasa Indonesia di SMA kelas XI berbasis kurikulum 2013. Berdasarkan silabus KD 4.9 relevansi penelitian ini dengan pembelajaran Bahasa Indonesia di SMA kelas XI dapat dimanfaatkan pada pembelajaran menulis teks cerpen. 


\section{Konteks: Membicarakan film}

\section{Deiksis Persona}

\section{Deiksis Persona Pertama}

(9) Fikho :"Enggak mas, aku emang hari ini libur".

(11) Fikho :"Aku kuliah di sana mas, di Balam”.

(21) Fikho : "Enggak punya aku mas, yang punya temen kuliahku, besoklah ku mintain sama dia".

(23) Fikho : "Kalau sekarang gak bisa mas.. soalnya rumah temenku jauh, bukan sekitar sini, rumah dia”.

(25) Fikho : "Ya udah besok aja, aku mintain sama dia ya mas”.

Pada pertuturan (9), (11), (21), (23), dan (25) terdapat pemakaian bentuk deiksis persona pertama tunggal karena menggunakan kata " $a k u$ ”, “-ku”, dan “ku-” sebagai kata gantinya. Penggunaan kata " $a k u ”$, “- $k u$ ”, dan " $k u$-" merujuk pada Fikho merupakan orang pertama atau yang mengucapkan tuturan kepada pihak lain (pihak kedua atau ketiga). Kata “aku”, “-ku”, dan " $k u$-” merupakan bentuk pemakaian persona pertama tunggal yang banyak digunakan dalam tuturan dan dalam keadaan yang tidak resmi yang banyak memperlihatkan kekariban antara penutur dan lawan tutur.

\section{Deiksis Persona Kedua}

(6) Fikho :"Lah kabarmu bagaimana?"

(15) Fikho :"Iya gitulah mas, lah kamu semester berapa sekarang?"

Pada pertuturan (6) dan terdapat pemakaian bentuk deiksis persona kedua tunggal karena menggunakan kata “- $m u$ ” dan "kamu”sebagai kata gantinya. Pemakaian kata “-mu” dan "kamu” adalah sebagai lawan bicara atau orang yang menjadi pendengar. Kata “-mu” dan "kamu” pada pertuturan (6) dan (15) mengacu pada peneliti sendiri sebagai lawan bicara Fikho. Pemakaian bentuk deiksis persona kedua tunggal pada kata “-mu” dan "kamu" merupakan pemakaian bentuk deiksis persona kedua tunggal yang bersifat tidak formal dengan kata lain kata “-mu” dan "kamu” dipakai pada situasi yang tidak formal dalam bentuk tunggal. Kata “-mu” dan "kamu” hanya dapat digunakan diantara peserta ujaran yang sudah akrab hubungannya, atau dipakai oleh orang yang berstatus sosial lebih tinggi untuk menyapa kawan bicara yang berstatus sosial lebih rendah, atau pihak yang berstatus sosial sama. 


\section{Deiksis Persona Ketiga}

(21) Fikho :"Enggak punya aku mas, yang punya temen kuliahku, besoklah ku mintain sama dia".

(23) Fikho :"Kalau sekarang gak bisa mas.. soalnya rumah temenku jauh, bukan sekitar sini, rumah dia".

(25) Fikho : "Ya udah besok aja, aku mintain sama dia ya mas".

Pada pertuturan (21), (23), dan (25) terdapat pemakaian bentuk deiksis persona ketiga tunggal karena menggunakan kata "dia" sebagai kata gantinya. Kata "dia" merupakan bentuk kata ganti orang ketiga tunggal. Penggunaan kata "dia” adalah sebagai orang yang tidak hadir dalam tempat terjadinya pembicaraan (tetapi menjadi bahan pembicaraan) atau yang hadir dekat dengan tempat pembicaraan (tetapi tidak terlibat). Kata "dia" pada pertuturan (21), (23), dan (25) mengacu pada teman kuliah Fikho yang sama-sama kuliah di Balam (Bandar Lampung). Teman kuliah Fikho merupakan orang yang tidak hadir dalam tempat terjadinya pembicaraan (tetapi menjadi bahan pembicaraan).

\section{Deiksis Tempat}

(11) Fikho :"Aku kuliah di sana mas, di Balam".

(23) Fikho :"Kalau sekarang gak bisa mas.. soalnya rumah temenku jauh, bukan sekitar sini, rumah dia".

Pada pertuturan (23) Menggunakan kata "sini" merupakan pemakaian bentuk deiksis tempat proksimal yaitu deiksis yang merujuk pada tempat yang dekat dengan penutur. Sedangkan pada pertuturan (11) merupakan pemakaian bentuk deiksis tempat distal yaitu deiksis yang merujuk pada tempat yang jauh dari penutur. Menggunakan kata "di sana”, dan penggunaan kata "di" di awal nama tempat yang rujukannya jauh dari si penutur " $d i$ Balam" (Bandar Lampung) termasuk deiksis tempat yang arahnya menjauhi penutur.

\section{Deiksis Waktu}

(9) Fikho :"Enggak mas, aku emang hari ini libur".

(15) Fikho :"Iya gitulah mas, lah kamu semester berapa sekarang?"

(21) Fikho :"Enggak punya aku mas, yang punya temen kuliahku, besoklah ku mintain sama dia".

(23) Fikho :"Kalau sekarang gak bisa mas.. soalnya rumah temenku jauh, bukan sekitar sini, rumah dia". 
(25) Fikho :"Ya udah besok aja, aku mintain sama dia ya mas".

Pada pertuturan (21), dan (25) merupakan pemakaian bentuk deiksis waktu distal yaitu waktu lampau ditinjau dari kata "besoklah" dan "besok". Pada pertuturan (21), dan (25) tersebut masingmasing merujuk pada waktu lampau. Sedangkan pada pertuturan (9), (15), dan (23) Merupakan pemakaian bentuk deiksis waktu proksimal yaitu waktu sekarang ditinjau dari kata "hari ini" dan "sekarang" mengacu pada waktu tuturan tersebut dituturkan yaitu Jumat pagi, 22 November 2019.

\section{Relevansi Penelitian pada}

\section{Pembelajaran Bahasa Indonesia}

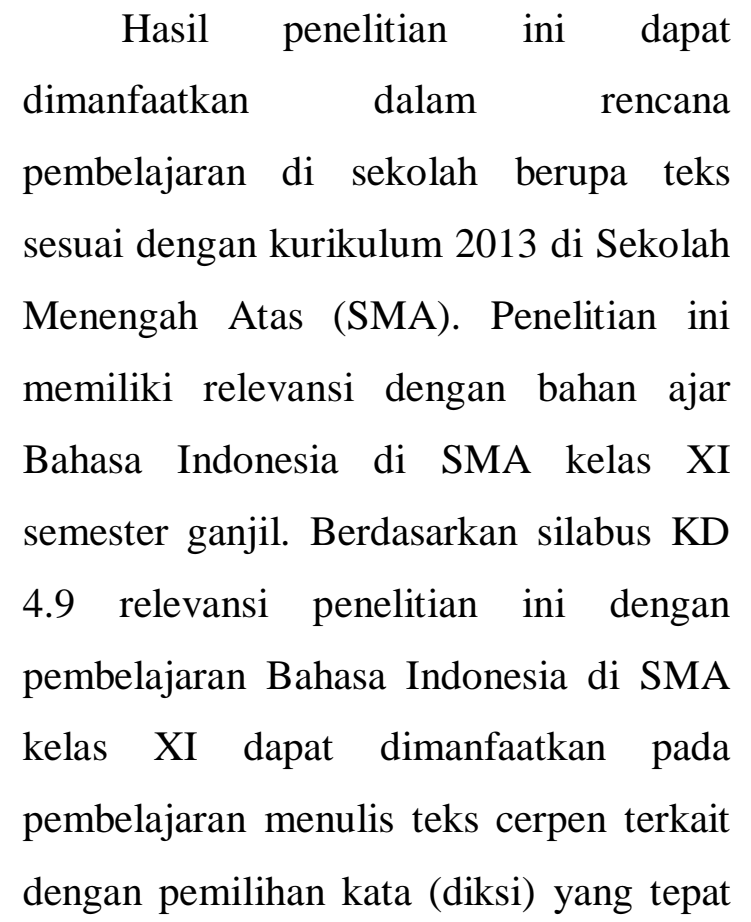

dan keefektifan kalimat pada penulisan teks cepen.

\section{SIMPULAN}

Berdasarkan analisis data ditemukan bentuk-bentuk deiksis pada tuturan masyarakat Desa Kalirejo. Deiksis persona yang ditemukan berfungsi sebagai kata ganti orang atau pemeran serta dalam peristiwa bahasa, Deiksis tempat yang ditemukan berfungsi sebagai kata ganti tempat atau penentu lokasi relatif dalam interaksi, dan deiksis waktu yang ditemukan dapat berfungsi sebagai kata ganti waktu atau penunjuk waktu relatif dalam interaksi. Hasil penelitian ini dapat digunakan dalam rencana pembelajaran di Sekolah berbasis kurikulum 2013. Relevansi penelitian ini dengan pembelajaran Bahasa Indonesia di SMA kelas XI yaitu dapat dimanfaatkan pada pembelajaran menulis teks cerita pendek terkait dengan pemilihan kata (diksi) yang tepat dan keefektifan kalimat pada penulisan teks cepen. 
Deiksis pada Pertuturan Masyarakat...

\section{DAFTAR PUSTAKA}

Abdul Chaer. (2010). Sosiolinguistik. Jakarta: Rineka Cipta.

Abdul Chaer. (2012). Linguistik Umum. Jakarta: Rineka Cipta.

Rahardi,Kunjana.,Setyaningsih,Yuliana., Dewi,R.P. (2016). Pragmatik Fenomena Ketidaksantunan Berbahasa. Jakarta : Erlangga.

Sugiyono. (2017). Metode Penelitian Pendidikan. Bandung : Alfabeta.

Suharsimi Arikunto. (2010) Prosedur Penelitian Suatu Pendekatan Praktik. Jakarta: Rineka Cipta

Yule, George. (2014). Pragmatik. Yogyakarta : Pustaka Pelajar. 